\title{
Powder and Solvent for Suspension for Injection Dosage Form
}

National Cancer Institute

\section{Source}

National Cancer Institute. Powder and Solvent for Suspension for Injection Dosage Form. NCl Thesaurus. Code C149802.

Sterile powder and sterile solvent intended for the preparation of a suspension for injection by dispersing the powder in the solvent. 